\title{
Assessing, mapping and quantifying cultural ecosystem services at community level ${ }^{1}$
}

Tobias Plieninger ${ }^{\mathrm{a}, \mathrm{b}^{*}}$, Sebastian Dijks ${ }^{\mathrm{b}}$, Elisa Oteros-Rozas ${ }^{\mathrm{c}} \&$ Claudia Bieling $^{\mathrm{d}}$

${ }^{a}$ Berlin-Brandenburg Academy of Sciences and Humanities, Ecosystem Services Research Group, Jägerstr. 22/23, 10117 Berlin, Germany

${ }^{\mathrm{b}}$ Humboldt-Universität zu Berlin, Geography Department, Unter den Linden 6, 10099 Berlin, Germany

${ }^{\mathrm{c}}$ Universidad Autónoma de Madrid, Social-Ecological Systems Laboratory, C/ Darwin 2, Edificio de Biología, 28049 Madrid, Spain

${ }^{d}$ University of Freiburg, Institute for Landscape Management, Tennenbacher Str. 4, 79106 Freiburg, Germany

* Corresponding author. Tel.: +49 3020370 538; fax: +49 3029370 214; E-mail: plieninger@bbaw.de (T. Plieninger)

\footnotetext{
${ }^{1}$ Preprint. Published version: Plieninger, T., Dijks, S., Oteros-Rozas, E. \& Bieling, C. (2013): Assessing, mapping, and quantifying cultural ecosystem services at community level, Land Use Policy 33 (2013), 118- 129. http://www.sciencedirect.com/science/article/pii/S026483771200258X
} 
Assessing, mapping and quantifying cultural ecosystem services at community level

\begin{abstract}
Numerous studies underline the importance of immaterial benefits provided by ecosystems and especially by cultural landscapes, which are shaped by intimate human-nature interactions. However, due to methodological challenges, cultural ecosystem services are rarely fully considered in ecosystem services assessments. This study performs a spatially explicit participatory mapping of the complete range of cultural ecosystem services and several disservices perceived by people living in a cultural landscape in Eastern Germany. The results stem from a combination of mapping exercises and structured interviews with 93 persons that were analyzed with statistical and GIS-based techniques. The results show that respondents relate diverse cultural services and multiple local-level sites to their individual well-being. Most importantly, aesthetic values, social relations and educational values were reported. Underlining the holistic nature of cultural ecosystem services, the results reveal bundles of services as well as particular patterns in the perception of these bundles for respondent groups with different socio-demographic backgrounds. Cultural services are not scattered randomly across a landscape, but rather follow specific patterns in terms of the intensity, richness and diversity of their provision. Resulting hotspots and coldspots of ecosystem services provision are related to landscape features and land cover forms. We conclude that, despite remaining methodological challenges, cultural services mapping assessments should be pushed ahead as indispensable elements in the management and protection of cultural landscapes. Spatially explicit information on cultural ecosystem services that incorporates the differentiated perceptions of local populations provides a rich basis for the development of sustainable land management strategies. These could realign the agendas of biodiversity conservation and cultural heritage preservation, thereby fostering multifunctionality.
\end{abstract}

\title{
Keywords
}

Biosphere reserve, Ecosystem services bundles, Germany, Landscape values, Participatory mapping, Socio-cultural perception 


\section{Introduction}

Fostering a broad range of ecosystem services has become a dominant environmental paradigm that has opened up important conservation opportunities around the world (de Groot et al., 2010). In the European Union, the idea of protecting and restoring the benefits that ecosystems provide to people has been promoted through the EU 2020 Biodiversity Strategy, which explicitly acknowledges biodiversity and ecosystem services as underpinnings of employment, economies, wealth, and well-being (European Commission, 2011). Corresponding ecosystem services assessments are currently being carried out throughout Europe, which is predominantly covered by "cultural landscapes" (Plieninger and Bieling, 2012). This latter term indicates that cultural services, one of the four pillars comprising common ecosystem services classifications, are of utmost importance. Cultural services, defined as "ecosystems' contributions to the non-material benefits (e.g. capabilities and experiences) that arise from human-ecosystems relationships" (Chan et al., 2012b: 9), are in general less directly linked to human well-being than provisioning and regulating services, but their potential for mediation is low (Millennium Ecosystem Assessment, 2005). In other words, locally degraded provisioning and regulating services may be substituted by socioeconomic means (e.g. drinking water from a polluted well can be replaced by bottled water), but the cultural values of an ecosystem or a landscape are irreplaceable. Accordingly, a recent global analysis has stressed that, although societies become less dependent on provisioning and regulating services in the course of a country's economic development, their dependency on cultural services increases (Guo et al., 2010).

Given the importance of cultural services for developed societies, it is surprising that cultural services - with the exception of recreation and tourism - are rarely considered in ecosystem services assessments (Feld et al., 2009). Cultural services differ in various aspects from other ecosystem services, presenting strong barriers toward their broader incorporation (Chan et al., 2012a; Chan et al., 2012b). The definitions of most cultural services categories are vague and, for many of them, it is difficult to establish significant relationships between ecosystem structures and functions and the satisfaction of human needs and wants (Daniel et al., 2012). Also, cultural services do not represent purely ecological phenomena, but rather are the outcome of complex and dynamic relationships between ecosystems and humans in landscapes over long time spans (Fagerholm et al., 2012). They are difficult to quantify in biophysical assessments, and their economic evaluation is generally subject to controversy. Moreover, their normative nature and the heterogeneity of their valuation by various stakeholders provide additional challenges (Rambonilaza and Dachary-Bernard, 2007; van Berkel and Verburg, 2012). However, many of these challenges, for example the subjectivity of enjoyment of ecosystem services, are inherent to other categories of ecosystem services as well, though rarely addressed explicitly (Daniel et al., 2012).

Incorporating cultural services into ecosystem services assessments is indispensable for comprehensive accounting of the contributions of ecosystems to human well-being and, thus, avoiding bias toward other ecosystem services and unwanted trade-offs in land management, but their integration is a challenging task (Schaich et al., 2010). Current research on ecosystem services is strongly focused on biophysical assessments, on the one hand, and on 
economic/monetary valuation exercises, on the other. A third, but largely overlooked, component of ecosystem services is the socio-cultural domain, which requires alternative evaluation approaches, drawing on a wide range of social science tools and methods (Daniel et al., 2012). To capture this dimension, it is essential to address cultural services and sociocultural preferences toward ecosystem services (Chan et al., 2012b). Studies of perceptions, values, attitudes, and beliefs may generate more meaningful insights regarding the contributions of ecosystem services to human well-being than purely biophysical assessments (Martín-López et al., 2012). In particular, they give more precise understanding of the relevance of ecosystem services for local stakeholders, allowing greater cultural sensitivity (Chan et al., 2012b) and recognition of trade-offs in ecosystem services valuation between different user groups, such as between tourists and local inhabitants (Fagerholm et al., 2012). Most perception studies (as reviewed by Martín-López et al., 2012) have revealed a preference for cultural services that is comparable in magnitude to preferences for regulating or providing ecosystem services.

Mapping exercises can be powerful tools for grasping the socio-cultural realities of communities, regions, landscapes, and ecosystems (Ryan, 2011). Cartographic representation of perceptions and preferences enables localization of the most highly valued ecosystems in a landscape (cultural services "hotspots", Bryan et al., 2010) and, consequently, identification of critical focal areas for cultural services management. Mapping the cultural services that stakeholders attribute to ecosystems also facilitates better comparison to provisioning and regulating services, thus informing effective analysis and negotiation of trade-offs between cultural services, biodiversity, commodity production, and other ecosystem services at landscape scale (Nelson et al., 2009). Additionally, such mapping may account for the spatial heterogeneity of ecosystem services demand, lack of which is a common limitation of economic valuation techniques (de Groot et al., 2010; Martin-Lopez et al., 2009). Mapping stakeholder perspectives also allows consideration of place-based ecological knowledge, which frequently deviates from literature- and model-based assessments (Fagerholm et al., 2012) and whose importance has been particularly highlighted in the process of establishing the Intergovernmental Science-Policy Platform on Biodiversity and Ecosystem Services (IPBES) (Turnhout et al., 2012). However, most of the small number of available studies (see Table A.1 for key examples) have covered only a few services, and only one study (with a focus on monetary valuation) has been performed in a European rural landscape (van Berkel and Verburg, 2012).

The present study aims to fill this gap by performing a spatially explicit mapping of the full range of cultural ecosystem services as perceived by local people. As it is increasingly being acknowledged that ecosystems not only provide benefits, but also various external costs (Dunn, 2010; Lyytimaki and Sipila, 2009), we additionally consider several disservices. The study was carried out in a study area in Eastern Germany, taking into account the specificities of cultural landscapes, in particular land cover mosaics and diversity of stakeholders. We were guided by the following research questions:

- What bundles of cultural services and disservices can emerge from diverging perceptions, and how can these differences be explained by socio-demographic determinants?

- How are the perceived (dis)services spatially distributed in the landscape? 
- What cultural (dis)services do people perceive in relation to different land covers?

\section{Study area}

The study was performed in five villages within the Upper Lusatia Pond and Heath Landscapes Biosphere Reserve, located in the eastern part of the state of Saxony in Germany (Fig. 1). The area covers 30,102 ha and has 12,800 inhabitants. The climate is subcontinental, with an average temperature of $8.5^{\circ} \mathrm{C}$ and an average precipitation of $630 \mathrm{~mm}$. Traditional fishing ponds and heathlands represent the most characteristic ecosystems of the area, with fish farming having an almost 800 year tradition. Keystone plant species are Erica tetralix, Drosera intermedia and Ledum palustre. Gray wolf (Canis lupus), European otter (Lutra lutra) and Eurasian elk (Alces alces) have been frequently recorded within the reserve (Bastian et al., 2005). The five villages in which the survey was performed - Brösa (197 inhabitants), Guttau (371 inhabitants), Kleinsaubernitz (344 inhabitants), Lömischau (123 inhabitants), and Wartha (153 inhabitants) - are part of the Guttau municipality and cover 1,950 ha. Land cover is composed of forests (29.6\%), cropland (28.2\%), grassland $(20.0 \%$, around $3 / 4$ of which are intensively managed agricultural grasslands and $1 / 4$ extensively used seminatural grasslands and heathlands), water bodies (12.0\%), settlements $(8.3 \%)$ and quarry (1.9\%) (Freistaat Sachsen, 2009). The municipality is a popular holiday and recreation destination, with a camping area, swimming lakes and further leisure opportunities. The water bodies are mainly traditional fish ponds and artificial lakes formed from former mining sites.

\section{Methods}

\subsection{Study design}

Our approach applied methods for social landscape values assessment and acquired local landscape knowledge through a combination of mapping and structured interviews, with subsequent integration into a geographical information system (GIS) (Brown, 2005; Fagerholm and Käyhkö, 2009; Tyrväinen et al., 2007). The overall study design was tested, discussed, and refined with students of an undergraduate class on "Land use and ecosystem services" at Humboldt-Universität zu Berlin during spring semester 2012. Information on cultural (dis)services was collected from individual respondents, but later analyzed collectively to derive local community values. Several techniques have been proposed to represent landscape values and special places when devising a map, for example:

a) delineating sites on the map through use of pencils or markers (Fagerholm et al., 2012; Klain and Chan, 2012),

b) using color-coded adhesive sticker dots for locating sites on the map (Brown, 2005; Raymond et al., 2009), or

c) pre-identifying and numbering special sites on the map and annotating them in a questionnaire (Tyrväinen et al., 2007).

After discussion of all three options in class, we decided for option c), as option a) would have implied costly digitization efforts and has high variability in terms of participant responses (Brown, 2005) while option b) would have required complicated handling during the field surveys, due to the relatively large number of services and disservices considered.

\subsection{Classification and indicators of cultural services}


Our exercise to account for cultural services began with the 10 categories established in the Millennium Ecosystem Assessment (2005). Following intensive class discussions, we dropped "cultural diversity" and "knowledge systems" from our list, as we felt unable to translate these services into indicators or questions that would be meaningful to landscape users at the local level. As recreation is one of the most important cultural services in the European context (Kenward and Sharp, 2008) and represents the probably most tangible cultural service, we asked about eight different recreational uses (walking, dog walking, horse riding, swimming, gathering wild food, angling, hunting, other uses). Additionally, we integrated three potential disservices (Table 1). As the Millennium Assessment does not formulate explicit definitions of cultural ecosystem services, we developed our own indicators, using generally one indicator question per service. For example, to gather aesthetic values, we asked: "Where in your community do you enjoy the beauty of the landscape?". We aimed to present the various services categories in a way that would be easily understood by respondents unfamiliar with the ecosystem services framework.

\subsection{Data collection}

Inhabitants of the five villages formed the survey population of this study. In May and June 2012, we performed 93 face-to-face interviews, a sample size comparable to that of other ecosystem services mapping exercises using community-scale interviews ${ }^{2}$. Each inquiry was conducted by two interviewers and took on average 20-30 minutes. We used a two-page questionnaire in German and a map of the case study area. The questionnaire and the map were discussed with colleagues - scientists and practitioners in natural resource management - and pre-tested with Bachelor students of agricultural sciences, many of whom originated from rural areas comparable to the study area. The questionnaire comprised 25 questions, mainly about site-specific information on cultural (dis)services in the study area. We used the most recent topographic map of the area (laminated, A3 format, at 1:20,000 scale) in which 38 coarse land cover units were pre-identified and numbered (compare Tyrväinen et al., 2007). These units were derived from the Saxony State Land-Use Map (Freistaat Sachsen, 2009). In some cases, areas were joined or separated to better reflect the areas most likely to be felt to be a homogeneous site, based on intensive site visits in August 2011.

The interviews started with an introduction into and clarification of the ecosystem services framework and the purpose of this study. Then, respondents were familiarized with the map of the study area and informed about the mapping process. The interviews centered on the following question: Where in this area do you find or use cultural services? They were asked to distinguish sites with cultural services and disservices on the map, one by one, for each (dis)service mentioned in Table 1. Interviewers wrote down the number of the site that respondents had attributed a certain (dis)service to. Respondents were allowed to mark up to three sites for each (dis)service and could identify other recreational uses of the study area that were not covered by the survey questions. Finally, a set of socio-demographic questions was asked regarding age, education, employment, and familiarity with the study area.

\footnotetext{
${ }^{2}$ Fagerholm et al., 2012: 218 respondents; Klain and Chan, 2012: 30 respondents; Raymond et al., 2009: 56 respondents; van Berkel and Verburg, 2012: 115 respondents
} 


\subsection{Data analysis}

In total, respondents assigned entries of 833 cultural services and of 82 disservices to various sites within their communities (Table A.2), which were entered into an Excel database and then transformed into a GIS. Thus, the identified (dis)service sites of the 93 respondents were joined with the layer of the 38 land cover units. ArcGIS 9.3 was used for spatial analyses, PASW (SPSS) 18, Excel 2003 and XSLSTAT 2012.4.01 for statistical analyses.

In a first analysis step, socio-demographic characteristics (gender, age, education, occupation, professional background, and frequency of landscape use outside settlements) of respondents were classified in absolute numbers and in relative proportion. Further, we listed the absolute and relative number of named cultural (dis)service indicators of all respondents $(n=93)$, the total number of entries $(n=915)$ and relative proportion compared to all entries, as well as the number of patches $(n=38)$ associated with the 18 ecosystem (dis)services. To analyze spatial relationships between pairs of ecosystem services, Spearman's rank correlation coefficient $(\rho)$ was applied. Then we performed a multiple correspondence analysis (MCA, an ordination technique for categorical data), to detect and represent any underlying structure in cultural services perceptions. The active variables were presence/absence of perception of an individual (dis)service; the socio-demographic characteristics were included as supplementary variables. In order to identify possible ecosystem services bundles according to interviewees' perceptions, we performed a hierarchical cluster analysis (HCA) through the Euclidean distance (percentage of distance similarity at a 95\% level of confidence) and Ward's agglomerative method with the standardized coordinates of the three first axes (Ward, 1963).

For cartographic representation, we merged the absolute number of perceived cultural services and disservices per land unit and displayed the perceived cultural services by respondents on separate maps. In addition, we conducted the mapping of aggregated patterns of cultural ecosystem (dis)services. For this purpose, intensity, richness and diversity of cultural services and intensity of disservices were calculated. In our case, intensity refers to the total number of mentioned service sites of all respondents, richness is the number of different services per land cover unit and diversity the ratio of entries per land cover unit and the distribution of mentioned services calculated with Shannon diversity index (H') (cf. Fagerholm et al., 2012). Furthermore, we calculated the number of entries for each cultural service and disservice per land cover (forest, cropland, grassland, water body, settlement, and quarry).

For the identification of ecosystem services bundles, we performed a principal components analysis (PCA) based on the correlation matrix of the variables' log-transformed frequency of ecosystem services in each land cover unit (Raudsepp-Hearne et al., 2010). We followed the Kaiser criterion (eigenvalue $>1$ ) to determine the significant number of components. In order to identify possible groups of patches with similar patterns in the provision of cultural services, we a) carried out an HCA based on the Euclidean distance and the Ward agglomerative method (Ward, 1963), using the coordinates of the most significant factors of the PCA, and b) calculated spatial autocorrelation of ecosystem services through Moran's I, a value indicating whether the data is spatially clustered or dispersed on a gradient from +1 to - 
1, respectively, where a value of 0 indicates a random pattern (Legendre and Legendre, 1998).

\section{Results}

\subsection{Characteristics of respondents}

Gender of respondents was well balanced, in accord with the composition of the local population, with $51 \%$ being women and $49 \%$ men (Table A.3). Only $14 \%$ of informants were under 30 years old, while $47 \%$ were between 30 and 60 , and $39 \%$ were above 60 . Fifty-four percent of respondents were employed, $40 \%$ were retired, and $2 \%$ were housewives, students, or jobless. Sixty-eight percent of respondents specified daily or near daily use of the landscape outside their settlements in summertime. Almost one third used the outer landscape a few times or once a week, and just 3\% less than once a week. In wintertime, respondents used the landscape less frequently, but still $38 \%$ responded that they were outside on a daily or nearly daily basis.

\subsection{Services and disservices}

Aesthetic values were the most frequently mentioned ecosystem service, followed by social relations, "other" recreational uses (specified mostly as bicycling), walking, and educational values (Fig. 2). Hunting, angling, and dog walking were only engaged in by small percentages of respondents, so they were merged with other similar services for later data analysis: hunting and angling with gathering wild products and dog walking with walking. Taken together, almost half of respondents specified at least one non-recreational cultural service. Disservices were perceived to a far lesser degree, and generally less than $30 \%$ of respondents mentioned any disservices in the area.

Spearman's rank correlation analysis showed that social relations were the ecosystem service with the most and strongest $(\rho>0.70)$ correlations, in particular related to spiritual values (0.78), inspiration (0.77), aesthetic values (0.70), and dog walking (0.72) (Table 2). Further, the pairs of aesthetic value and other recreation $(0.77)$, as well as gathering wild products and scariness (0.75) showed a strong correlation. Inspiration (10) was the service class with the highest number of strong and medium correlations, followed by aesthetic values (9), social relations (8), and other recreation (8).

The first two axes of the MCA accounted for $68 \%$ of the inertia (Fig. 3, Table A.4). The first axis $(36 \%$ of inertia) was explained by the perception of all ecosystem services being positively and significantly related with older, retired people who use to go out into the landscape on a daily basis. The second axis (32\% of inertia) clearly separated on the positive side mainly recreational services and all disservices, while putting on the negative side those services more related to the satisfaction of the immaterial dimension of human well-being (social relations, cultural heritage values, educational values, and inspiration). Men and employees were significantly related to the former values and women to the latter ones. This clear categorization of ecosystem services was largely confirmed by the HCA (Fig. A.1) that distinguished two groups or bundles of ecosystem services according to people's perceptions: one formed by the three disservices and swimming, gathering wild products, hunting and 
angling (mainly recreational services); and the other grouping the remaining cultural services (stronger immaterial dimension).

\subsection{Spatial patterns of cultural services}

Assignations of individual cultural services and disservices to specific sites are depicted in Fig. 4. Most entries (between 20 and 41) of single services (walking, swimming, aesthetics and education) were allocated to and around the fishing ponds and the largest lake (Lake $O l b a$ ) in the area. Social relations, sense of place, and inspiration were most frequently ascribed to the settlement area of Guttau und Brösa (10-20 entries). The disservices unpleasantness and noisiness were concentrated around the Kleinsaubernitz settlement and a campground. Scariness was mainly ascribed to forest areas. Grasslands, croplands, and the quarry in the south were hardly related to perceived cultural ecosystem services.

These tendencies were confirmed by the aggregated patterns of cultural ecosystem services and disservices. The highest intensity of cultural ecosystem services was observed close to lakes, fishing ponds, settlements and the campground with surrounding forest. Richness and diversity of cultural services were also highest at Lake Olba and the campground. While both sites featured 13 different ecosystem services, the Shannon diversity index differed slightly between 2.37 (lake) and 2.22 (campground). High richness $(n=11)$ was found in northeastern grassland. Higher levels of diversity appeared in the settlements of Wartha $\left(H^{\prime}=2.22\right)$ and Brösa $\left(\mathrm{H}^{\prime}=2.03\right)$, croplands $\left(\mathrm{H}^{\prime}=2.14\right)$ in the western part, a forest patch $\left(\mathrm{H}^{\prime}=2.03\right)$ in the east of the study area and at a water body $\left(H^{\prime}=2.02\right)$ close to Kleinsaubernitz. Coldspots of intensity, richness and diversity occurred in the south (Fig. 5). Hotspots of intense disservices were the Kleinsaubernitz settlement, the nearby lake, and the campground.

\subsection{Relationship to land cover}

The six main land cover types of the area (forest, cropland, grassland, water body, settlement, and quarry) are used for different purposes and exhibited, therefore, disparate relationships to ecosystem services perceptions. The most frequently used sites, or those with the highest immaterial value for community members, were related to water bodies or settlements (Table A.5). Social relations were ascribed 63 times to settlements, sense of place 41 times, and spiritual values 29 times. In and around water bodies, aesthetic values (57), walking (52) and swimming (47) were commonly named. Forests and grasslands were most frequently associated with gathering wild products such as mushrooms, fruits and firewood, learning about plant and animals species (educational value) and walking.

This spatial distribution of ecosystem services was reflected in the PCA, in which the first two axes accounted for $68 \%$ of variance (Fig. 6, Table A.6). The first axis (54\% of variance) was significantly and positively related to most cultural services, especially walking, aesthetic values, sense of place, inspiration, educational values, spiritual values, and cultural heritage values, as well as unpleasantness. The second axis (14\% of variance) represented on the positive side forests and gathering wild products, hunting, angling and scariness and was negatively related to settlements and noisiness.

\section{Discussion}




\subsection{Cultural ecosystem services at landscape level}

This study sought to apply and advance an approach for assessing the cultural ecosystem services that people perceive and enjoy at the level of communities. Our findings confirm that people relate diverse cultural services and multiple local-level sites to their individual wellbeing. From the list of cultural services, more than half of the respondents were able to identify sites of particular aesthetic values, social relations, or educational values. Among the recreational services, walking and others (mainly specified as bicycling) were highly important for most participants. Most of these services are overlooked by conventional biophysical and economic ecosystem services assessments and, therefore, are underappreciated compared to other more easily quantifiable ecosystem services (Gee and Burkhard, 2010; Norton et al., 2012). To better balance assessments of material ecosystem services with intangible cultural services in landscapes inhabited and used by local people, landscape-level socio-cultural studies need to be introduced into the science of ecosystem services (Chan et al., 2012b). Using cultural landscape approaches in ecosystem services assessments would help to better realize the philosophy of the European Landscape Convention, which specifies a landscape as "an area, as perceived by people, whose character is the result of the action and interaction of natural and/or human factors" (COE, 2000). Further, our study documents that people find various cultural values in their everyday surroundings, not only in landscapes of outstanding biodiversity, heritage, or scenery.

Disservices have been recently added to the ecosystem services framework, but less than 30\% of respondents attributed disservices to sites within their communities. Most referred to noise and waste in the landscape, which is a consequence of human use of ecosystems, not a disservice from the ecosystem itself. Similarly, most disservices that Agbenyega et al. (2009) recorded in British woodlands were not directly related to ecosystems, such as fly-tipping, dog excrement, or drug use. However, these disservices may give some indication of local overuse of recreational services. The only disservice mentioned that was clearly related to ecological structures or functions was the perceived fear of wolves that are prowling through the region, mainly in the forests.

\subsection{Cultural services hotspots and coldspots}

Our results indicate that many cultural services are not scattered randomly across the landscape, but rather occur in particular patterns, leading to the expression of distinct hotspots and coldspots of cultural services (compare van Berkel and Verburg, 2012; Willemen et al., 2008). Aggregation indices - here, intensity, richness, and diversity of cultural services point to different facets of cultural values in landscapes and are useful for identifying priority areas (Bryan et al., 2010). In our case, all indices point in similar directions by attributing high service values to a few sites, in particular to Lake Olba, settlements, and fish ponds.

Our study also shows that assignment of cultural (dis)services was related to particular ecosystems and spatial properties. Settlements and grasslands close to villages seem particular meaningful for feeling a sense of place, for social relations, and partly for spiritual values and inspiration, but have the highest level of noisiness. Water bodies were of utmost importance for recreation, education, aesthetics, and as heritage sites; forests had some importance for education and spirituality. In contrast, cropland and quarry sites were hardly 
attributed any cultural services, thus forming coldspots of ecosystem services. This broadly corresponds to English and Dutch studies (Norton et al., 2012; van Berkel and Verburg, 2012) wherein linkages of cultural services to physical landscape features have been detected, in particular to woodlands, water, geographical relief, and coastal areas (in England) and to cultural buildings, tree lines, lakes and rivers, forests, and semi-managed landscape structures (in the Netherlands).

\subsection{Bundles in the perception of cultural services}

Our findings expand on previous insight (Suckall et al., 2009; van Berkel and Verburg, 2012) that individual people perceive cultural services differently according to their backgrounds, even at homogeneous local scales. Respondent age, gender, employment, and frequency of landscape visits in summer were particularly decisive for separating respondent groups. Gender differences in the perception of ecosystem services have previously been assessed (Martín-López et al., 2012) and justified in accordance with gender-differentiated environmental awareness (Dietz et al., 2002) and roles (Reyes-Garcia et al., 2010). Similar to the latter factor, Soini et al. (2012) had identified awareness and familiarity with local surroundings as important determinants of landscape perception. The results of our MCA suggest that the activity-based recreational services are fundamentally different in character than the less utilitarian cultural services.

The many positive and significant correlations between assigned ecosystem services show that there is considerable overlap between individual services, indicating that people do not clearly separate one cultural service category from the other. This can be understood - and appreciated - as evidence of the interlinked, holistic nature of cultural ecosystem services (Bieling and Plieninger, 2012; Daniel et al., 2012). These results further confirm the "bundled" occurrence of cultural services (Raudsepp-Hearne et al., 2010). Surprisingly, even some services and disservices were positively correlated. For example, many sites (in particular forest sites) were enjoyed for gathering of wild products, but at the same time were places of scariness, mostly related to potentially roaming wolves and remnant ammunition from the former military training site in this area.

Our finding of "bundled" cultural services is of relevance for a potential upscaling of cultural services assessments. The European Union has obliged all member countries to map and assess ecosystem services (including cultural services) by 2014 (European Commission, 2011). As national or Europe-wide assessments will hardly be able to assess the full list of cultural ecosystem services, our study gives some guidance on how to focus such upscaling efforts: We demonstrate that the assessment of the recreational services bundle is clearly different from a second bundle that is more related to the cognitive meanings of landscapes and ecosystems. Narrowing mapping efforts on these broad groups may allow reducing the number of cultural services categories while capturing the essence of cultural ecosystem services.

\subsection{Challenges}

To capture the full potential of such cultural services assessments and to enhance planning and management, data need to be combined with spatially explicit information on biodiversity 
and other ecosystem services (Raymond et al., 2009). However, our study, together with previous cultural services mapping assessments (Table A.1), entered largely uncharted territories, and several challenges inhibit broader integration of cultural services mapping. Here, we point to problematic aspects of spatial scale and delimitation of cultural services and of participant selection that we encountered in our study.

The appropriate spatial scale of ecosystem services assessments is a much discussed question (Hein et al., 2002). Following the emphasis of the European Landscape Convention on the local scale, our approach focused on local communities. However, participants commonly assigned cultural services to sites outside our study areas, which could not be taken up through our approach. For example, cultural heritage was more often attributed to outstanding features in the state of Saxony than to specific sites within their local communities. Furthermore, the challenge of appropriate spatial scales is particularly strong for cultural services, as many of them are perceived by the eye over distant views (Norton et al., 2012), ultimately leading to mismatches between the scales and boundaries of ecosystems and cultural services (de Groot et al., 2010). The blurred spatial properties of the "service providing units" of cultural ecosystem services represent additional challenges. As most ecosystem services are related to specific landscape attributes (Brown, 2005), we preidentified sites according to land cover units. However, some cultural services such as inspiration or spiritual values are not intuitively associated with any particular landscape attribute (Brown, 2005), and so our procedure may have biased the results. Certainly, finergrained information about the physical landscape properties that provide cultural services (beyond the simple extent of certain land cover) is needed (Norton et al., 2012). However, alternative mapping methods such as having respondents delimit service providing units by markers or sticker dots involve similar or other inaccuracies (Fagerholm and Käyhkö, 2009), and a "best" method has not been identified so far. Triangulation processes (Lynam et al., 2007), for example through complementary qualitative approaches such as a in-depth interviews among respondents about how and why they appreciate a particular site for a specific service, may present a pathway to more robust insight (Tyrväinen et al., 2007).

Local inhabitants formed the population of this study, but the area is also a popular recreational destination for outside visitors. We did not assess ecosystem services perceptions from such group, although these may appreciate cultural services in this place rather differently (cf. Rambonilaza and Dachary-Bernard, 2007). One evident example is the assessment of the wolf population of the area. Whereas wolf conservation is generally supported at national level, in particular by urban people (Thiel et al., 2012), the inhabitants of our rural study area expressed more negative attitudes. Another difference may be found in the perception of the "built capital" in the landscape, i.e. the villages. Local people attached many cultural services (most notably social relations) to their villages, whereas visitors according to our personal observation - come to the area primarily for its "natural capital", for example its wildlife, its swimming lakes, and its scenic pond landscapes. Therefore, spatial scales and the character of the sampled stakeholders need to be explicitly revealed in any cultural services assessment (Norton et al., 2012).

\subsection{Implications for nature conservation and landscape planning}


Our assessment of cultural services was performed in a nature reserve, within one of Germany's socially and economically marginalized regions where a regional economic development paradigm frequently dominates over nature conservation concerns (Beetz et al., 2008). Protected areas in Germany, in particular existing and proposed National Parks (e.g. Bavarian Forest, Northern Black Forest), have recently experienced opposition (Müller and Job, 2009), as many local people feel that conservation aims or practices (for example, nonintervention on bark beetle outbreaks) do not correspond to their cultural sensitivities (StollKleemann, 2001). Therefore, there is an urgent need to devise better conservation mechanisms that provide clear benefits to local people (DeFries et al., 2007), and capitalizing on the cultural services of protected areas may be one way of doing so (Daniel et al., 2012). In combination with expert-based perspectives, identification of cultural values of local people and targeting of management actions to hotspots of local concern may build trust, increase political support, and ultimately improve environmental outcomes (Raymond et al., 2009; Sherrouse et al., 2011; Stephenson, 2008). Furthermore, awareness of cultural services may be particularly helpful for recoupling the disparate agendas of biodiversity conservation and cultural heritage preservation (Tengberg et al., 2012)

Our results indicate that recreational uses may be a particularly powerful means for supporting conservation in German protected areas. It has been recently highlighted that recreational landscape users may provide important contributions toward improved management of ecosystem services, long-term monitoring of species and ecosystem dynamics, and public awareness for nature conservation and sustainable land use (Conrad and Hilchey, 2011). A pan-European evaluation of governance and ecosystem management has shown that biodiversity and ecosystem services are most effectively safeguarded through consideration of the perspectives of local ecosystem users, the variety of which are surprisingly numerous in most European countries (Kenward et al., 2011). However, it is well-known that many cultural services, for example inspiration or sense of place, are related to extracting activities such as hunting, fishing, or mushroom gathering (Chan et al., 2012b). This jointness of cultural and provisioning services presents a challenge for hands-off conservation approaches as traditionally practiced in the core zones of many nature reserves. At the same time, use of cultural services opens up opportunities for more inclusive strategies, commonly labeled as sustainable use (Hutton and Leader-Williams, 2003) or cultural landscape (Plieninger and Bieling, 2012) approaches.

The capacity of ecosystems and landscapes to supply direct or indirect benefits to society has long been assessed in landscape planning, in particular in the human-shaped landscapes of central Europe (Ansink et al., 2008). However, this functional approach has never received such popularity in the environmental science and policy realms as the ecosystem services approach, which is centered on the goods and services that ecosystems and landscapes provide (von Haaren and Albert, 2011). An ecosystem or landscape function translates into a service as soon as there is a societal demand for this function. Our study supports the view that a collaborative, demand-side assessment of cultural services should become part of landscape planning (Termorshuizen and Opdam, 2009), thus incorporating the value that local people attach to landscapes and overcoming the one-sidedness of expert-based approaches (Martínez-Harms and Balvanera, 2012). While ecosystem services research has been 
successful in identifying the trade-offs between land cover and land use change and ecosystem services (de Groot et al., 2010), this research highlights the need to identify synergies in the form of ecosystem services bundles in order to guide landscape development toward multifunctionality and sustainability (Reyers et al., 2012; Selman, 2012).

\section{Conclusions}

Do cultural services play a central role for sustainable land management throughout the world or are our findings from a German nature reserve rather unique? And should consideration of "soft" cultural ecosystem services really receive stronger weight, given the "hard" facts that many vital provisioning and regulating services are close to irreversibly transgressing planetary boundaries (Rockstrom et al., 2009)? We suggest that stronger awareness regarding cultural ecosystem services and their socio-cultural valuation may be of relevance for nature conservation and sustainable land management for two reasons. First, cultural services are, in contrast to most regulating and supporting services, directly experienced and intuitively appreciated by people (Daniel et al., 2012; Schaich et al., 2010). Therefore, they are motivators for owning, managing, and conserving land (Chan et al., 2012a), often being even more important than traditional livestock or timber production (e.g. Bieling, 2004; Plieninger et al., 2012a). Second, most cultural services are enjoyed in "bundles" and can thus foster the orientation of ecosystem services management toward multifunctionality, which is a frequently expressed, but rarely achieved desideratum in land-use science and policy (Cowie et al., 2007; Plieninger et al., 2012b). As such, the holistic nature of cultural services can help overcome the widespread tendency to design incentive tools for individual ecosystem services in isolation, which often has been accompanied by unintended side-effects on other ecosystem services.

\section{Acknowledgements}

We thank the communities of Brösa, Guttau, Kleinsaubernitz, Lömischau, and Wartha and, particularly, all participants in the survey. We are grateful to B. Ohnesorge, C. Schleyer, and the spring 2012 students of our "Land use and ecosystem services" class at HumboldtUniversität zu Berlin for extensive discussion of the study design and their help in the performance of the survey. We are grateful to two anonymous reviewers for their constructive feedback and to Chris Hank for improving the language of the paper. The study was supported by grant 01UU0904 from the German Federal Ministry of Education and Research (BMBF).

\section{References}

Agbenyega, O., Burgess, P.J., Cook, M., Morris, J., 2009. Application of an ecosystem function framework to perceptions of community woodlands. Land Use Policy 26, 551-557.

Ansink, E., Hein, L., Hasund, K.P., 2008. To value functions or services? An analysis of ecosystem valuation approaches. Environmental Values 17, 489-503.

Bastian, O., Porada, H.T., Röder, M., Syrbe, R.-U., 2005. Oberlausitzer Heide- und Teichlandschaft. Landschaften in Deutschland 67. Böhlau, Cologne, Weimar, Vienna. 
Beetz, S., Huning, S., Plieninger, T., 2008. Landscapes of peripherization in North-Eastern Germany's countryside: New challenges for planning theory and practice. International Planning Studies 13, 295-310.

Bieling, C., 2004. Non-industrial private-forest owners: possibilities for increasing adoption of close-to-nature forest management. European Journal of Forest Research 123, 293-303.

Bieling, C., Plieninger, T., 2012. Recording manifestations of cultural ecosystem services in the landscape. Landscape Research, doi: 10.1080/01426397.01422012.01691469.

Brown, G., 2005. Mapping spatial attributes in survey research for natural resource management: Methods and applications. Society \& Natural Resources 18, 17-39.

Bryan, B.A., Raymond, C.M., Crossman, N.D., Macdonald, D.H., 2010. Targeting the management of ecosystem services based on social values: Where, what, and how? Landscape and Urban Planning 97, 111-122.

Chan, K.M.A., Guerry, A.D., Balvanera, P., Klain, S., Satterfield, T., Basurto, X., Bostrom, A., Chuenpagdee, R., Gould, R., Halpern, B.S., Hannahs, N., Levine, J., Norton, B., Ruckelshaus, M., Russell, R., Tam, J., Woodside, U., 2012a. Where are cultural and social in ecosystem services? A framework for constructive engagement. Bioscience 62, 744-756.

Chan, K.M.A., Satterfield, T., Goldstein, J., 2012b. Rethinking ecosystem services to better address and navigate cultural values. Ecological Economics 74, 8-18.

COE, 2000. European Landscape Convention. European Treaty Series - No. 176. Council of Europe, Florence.

Conrad, C.C., Hilchey, K.G., 2011. A review of citizen science and community-based environmental monitoring: issues and opportunities. Environmental Monitoring and Assessment 176, 273-291.

Cowie, A., Schneider, U.A., Montanarella, L., 2007. Potential synergies between existing multilateral environmental agreements in the implementation of land use, land-use change and forestry activities. Environmental Science \& Policy 10, 335-352.

Daniel, T.C., Muhar, A., Arnberger, A., Aznar, O., Boyd, J.W., Chan, K.M.A., Costanza, R., Elmqvist, T., Flint, C.G., Gobster, P.H., Gret-Regamey, A., Lave, R., Muhar, S., Penker, M., Ribe, R.G., Schauppenlehner, T., Sikor, T., Soloviy, I., Spierenburg, M., Taczanowska, K., Tam, J., von der Dunk, A., 2012. Contributions of cultural services to the ecosystem services agenda. Proceedings of the National Academy of Sciences of the United States of America $109,8812-8819$.

de Groot, R.S., Alkemade, R., Braat, L., Hein, L., Willemen, L., 2010. Challenges in integrating the concept of ecosystem services and values in landscape planning, management and decision making. Ecological Complexity 7, 260-272. 
DeFries, R., Hansen, A., Turner, B.L., Reid, R., Liu, J.G., 2007. Land use change around protected areas: Management to balance human needs and ecological function. Ecological Applications 17, 1031-1038.

Dietz, T., Kalof, L., Stern, P.C., 2002. Gender, values, and environmentalism. Social Science Quarterly 83, 353-364.

Dunn, R.R., 2010. Global mapping of ecosystem disservices: The unspoken reality that nature sometimes kills us. Biotropica 42, 555-557.

European Commission, 2011. Our Life Insurance, our Natural Capital: an EU Biodiversity Strategy to 2020. SEC(2011) 540 final, SEC(2011) 541 final, Brussels.

Fagerholm, N., Käyhkö, N., 2009. Participatory mapping and geographical patterns of the social landscape values of rural communities in Zanzibar, Tanzania. Fennia 187, 43-60.

Fagerholm, N., Käyhkö, N., Ndumbaro, F., Khamis, M., 2012. Community stakeholders' knowledge in landscape assessments - Mapping indicators for landscape services. Ecological Indicators 18, 421-433.

Feld, C.K., da Silva, P.M., Sousa, J.P., de Bello, F., Bugter, R., Grandin, U., Hering, D., Lavorel, S., Mountford, O., Pardo, I., Partel, M., Rombke, J., Sandin, L., Jones, K.B., Harrison, P., 2009. Indicators of biodiversity and ecosystem services: a synthesis across ecosystems and spatial scales. Oikos 118, 1862-1871.

Freistaat Sachsen, 2009. Aktualisierung der Biotopkartierung in Sachsen. Kartieranleitung Sächsisches Landesamt für Umwelt, Landwirtschaft und Geologie Dresden.

Gee, K., Burkhard, B., 2010. Cultural ecosystem services in the context of offshore wind farming: A case study from the west coast of Schleswig-Holstein. Ecological Complexity 7 , 349-358.

Guo, Z.W., Zhang, L., Li, Y.M., 2010. Increased dependence of humans on ecosystem services and biodiversity. Plos One 5.

Hein, L., van Koppen, K., de Groot, R.S., van Ierland, E.C., 2002. Spatial scales, stakeholders and the valuation of ecosystem services. Ecological Economics 57, 209-228.

Hutton, J.M., Leader-Williams, N., 2003. Sustainable use and incentive-driven conservation: realigning human and conservation interests. Oryx 37, 215-226.

Kenward, R., Sharp, R., 2008. Use Nationally of Wild Resources across Europe (UNWIRE). GEM-CON-BIO Case Study Matrix Report (http://www.gemconbio.eu/downloads/gemconbio_unwire_april_2008.pdf).

Kenward, R.E., Whittingham, M.J., Arampatzis, S., Manos, B.D., Hahn, T., Terry, A., Simoncini, R., Alcorn, J., Bastian, O., Donlan, M., Elowe, K., Franzen, F., Karacsonyi, Z., Larsson, M., Manou, D., Navodaru, I., Papadopoulou, O., Papathanasiou, J., von Raggamby, 
A., Sharp, R.J.A., Soderqvist, T., Soutukorva, A., Vavrova, L., Aebischer, N.J., LeaderWilliams, N., Rutz, C., 2011. Identifying governance strategies that effectively support ecosystem services, resource sustainability, and biodiversity. Proceedings of the National Academy of Sciences of the United States of America 108, 5308-5312.

Klain, S.C., Chan, K.M.A., 2012. Navigating coastal values: Participatory mapping of ecosystem services for spatial planning. Ecological Economics.

Legendre, P., Legendre, L., 1998. Numerical Ecology. Elsevier, Amsterdam.

Lynam, T., de Jong, W., Sheil, D., Kusumanto, T., Evans, K., 2007. A review of tools for incorporating community knowledge, preferences, and values into decision making in natural resources management. Ecology and Society 12.

Lyytimaki, J., Sipila, M., 2009. Hopping on one leg - The challenge of ecosystem disservices for urban green management. Urban Forestry \& Urban Greening 8, 309-315.

Martin-Lopez, B., Gomez-Baggethun, E., Lomas, P.L., Montes, C., 2009. Effects of spatial and temporal scales on cultural services valuation. Journal of Environmental Management 90, 1050-1059.

Martín-López, B., Iniesta-Arandia, I., García-Llorente, M., Palomo, I., Casado-Arzuaga, I., García Del Amo, D., Gómez-Baggethun, E., Oteros-Rozas, E., Palacios-Agundez, I., Willaarts, B., González, J.A., Santos-Martín, F., Onaindia, M., López-Santiago, C., Montes, C., 2012. Uncovering Ecosystem Service Bundles through Social Preferences. Plos One 7, e38970.

Martínez-Harms, M.J., Balvanera, P., 2012. Methods for mapping ecosystem service supply: a review. International Journal of Biodiversity Science, Ecosystem Services \& Management $8,17-25$.

Millennium Ecosystem Assessment, 2005. Ecosystems and Human Well-Being: Synthesis. Island Press, Washington, D.C.

Müller, M., Job, H., 2009. Managing natural disturbance in protected areas: Tourists' attitude towards the bark beetle in a German national park. Biological Conservation 142, 375-383.

Nelson, E., Mendoza, G., Regetz, J., Polasky, S., Tallis, H., Cameron, D.R., Chan, K.M.A., Daily, G.C., Goldstein, J., Kareiva, P.M., Lonsdorf, E., Naidoo, R., Ricketts, T.H., Shaw, M.R., 2009. Modeling multiple ecosystem services, biodiversity conservation, commodity production, and tradeoffs at landscape scales. Frontiers in Ecology and the Environment 7, 411.

Norton, L.R., Inwood, H., Crowe, A., Baker, A., 2012. Trialling a method to quantify the 'cultural services' of the English landscape using Countryside Survey data. Land Use Policy 29, 449-455. 
Plieninger, T., Bieling, C., 2012. Resilience and the Cultural Landscape: Understanding and Managing Change in Human-Shaped Environments. Cambridge University Press, Cambridge.

Plieninger, T., Ferranto, S., Huntsinger, L., Kelly, M., Getz, C., 2012a. Appreciation, use, and management of biodiversity and ecosystem services in California's working landscapes. Environmental Management 50, 427-440.

Plieninger, T., Schleyer, C., Schaich, H., Ohnesorge, B., Gerdes, H., Hernández-Morcillo, M., Bieling, C., 2012b. Mainstreaming ecosystem services through reformed European agricultural policies. Conservation Letters 5, 281-288.

Rambonilaza, M., Dachary-Bernard, J., 2007. Land-use planning and public preferences: What can we learn from choice experiment method? Landscape and Urban Planning 83, 318326.

Raudsepp-Hearne, C., Peterson, G.D., Bennett, E.M., 2010. Ecosystem service bundles for analyzing tradeoffs in diverse landscapes. Proceedings of the National Academy of Sciences of the United States of America 107, 5242-5247.

Raymond, C.M., Bryan, B.A., MacDonald, D.H., Cast, A., Strathearn, S., Grandgirard, A., Kalivas, T., 2009. Mapping community values for natural capital and ecosystem services. Ecological Economics 68, 1301-1315.

Reyers, B., O'Farrell, P.J., Nel, J.L., Wilson, K., 2012. Expanding the conservation toolbox: conservation planning of multifunctional landscapes. Landscape Ecology 27, 1121-1134.

Reyes-Garcia, V., Vila, S., Aceituno-Mata, L., Calvet-Mir, L., Garnatje, T., Jesch, A., Lastra, J.J., Parada, M., Rigat, M., Valles, J., Pardo-de-Santayana, M., 2010. Gendered homegardens: A study in three mountain areas of the Iberian Peninsula. Economic Botany 64, 235-247.

Rockstrom, J., Steffen, W., Noone, K., Persson, A., Chapin, F.S., Lambin, E.F., Lenton, T.M., Scheffer, M., Folke, C., Schellnhuber, H.J., Nykvist, B., de Wit, C.A., Hughes, T., van der Leeuw, S., Rodhe, H., Sorlin, S., Snyder, P.K., Costanza, R., Svedin, U., Falkenmark, M., Karlberg, L., Corell, R.W., Fabry, V.J., Hansen, J., Walker, B., Liverman, D., Richardson, K., Crutzen, P., Foley, J.A., 2009. A safe operating space for humanity. Nature 461, 472-475.

Ryan, R.L., 2011. The social landscape of planning: Integrating social and perceptual research with spatial planning information. Landscape and Urban Planning 100, 361-363.

Schaich, H., Bieling, C., Plieninger, T., 2010. Linking ecosystem services with cultural landscape research. GAIA 19, 269-277.

Selman, P.H., 2012. Sustainable Landscape Planning: The Reconnection Agenda. Routledge, Milton Park, New York.

Sherrouse, B.C., Clement, J.M., Semmens, D.J., 2011. A GIS application for assessing, mapping, and quantifying the social values of ecosystem services. Applied Geography 31, 748-760. 
Soini, K., Vaarala, H., Pouta, E., 2012. Residents' sense of place and landscape perceptions at the rural-urban interface. Landscape and Urban Planning 104, 124-134.

Stephenson, J., 2008. The cultural values model: An integrated approach to values in landscapes. Landscape and Urban Planning 84, 127-139.

Stoll-Kleemann, S., 2001. Reconciling opposition to protected areas management in Europe: The German experience. Environment 43, 32-44.

Suckall, N., Fraser, E.D.G., Cooper, T., Quinn, C., 2009. Visitor perceptions of rural landscapes: A case study in the Peak District National Park, England. Journal of Environmental Management 90, 1195-1203.

Tengberg, A., Fredholm, S., Eliasson, I., Knez, I., Saltzman, K., Wetterberg, O., 2012. Cultural ecosystem services provided by landscapes: Assessment of heritage values and identity. Ecosystem Services.

Termorshuizen, J.W., Opdam, P., 2009. Landscape services as a bridge between landscape ecology and sustainable development. Landscape Ecology 24, 1037-1052.

Thiel, A., Schleyer, C., Plieninger, T., 2012. Wolves are mobile, While fruit trees are not! How characteristics of resources and supranational regulatory frameworks shape the provision of biodiversity and ecosystem services in Germany. Environmental Policy and Governance 22, 189-204.

Turnhout, E., Bloomfield, B., Hulme, M., Vogel, J., Wynne, B., 2012. Listen to the voices of experience. Nature 488, 454-455.

Tyrväinen, L., Mäkinen, K., Schipperijn, J., 2007. Tools for mapping social values of urban woodlands and other green areas. Landscape and Urban Planning 79, 5-19.

van Berkel, D.B., Verburg, P.H., 2012. Spatial quantification and valuation of cultural ecosystem services in an agricultural landscape. Ecological Indicators doi: 10.1016/j.ecolind.2012.06.025.

von Haaren, C., Albert, C., 2011. Integrating ecosystem services and environmental planning: limitations and synergies. International Journal of Biodiversity Science, Ecosystem Services \& Management 7, 150-167.

Ward, J.H., 1963. Hierarchical grouping to optimize an objective function. Journal of the American Statistical Association 58, 236-\&.

Willemen, L., Verburg, P.H., Hein, L., van Mensvoort, M.E.F., 2008. Spatial characterization of landscape functions. Landscape and Urban Planning 88, 34-43. 


\section{Tables}

\section{Table 1}

Selected cultural ecosystem services and disservices and their definitions as understood in this study

\section{Table 2}

Spatial relationships as expressed by Spearman's rank correlation coefficient $(\rho)$ between pairs of ecosystem services $\left(\mathrm{n}=38 ;{ }^{*} \mathrm{P}<0.05 ;^{* *} \mathrm{P}<0.01 ;{ }^{* * *} \mathrm{P}<0.001\right)$. Grey shading indicates strong positive correlations $(\rho=0.50-0.69)$, dark grey very strong positive correlations ( $\rho$ $\geq 0.70)$ 


\section{Table 1}

Selected cultural ecosystem services and disservices and their definitions as understood in this study

\begin{tabular}{ll}
\hline (Dis)service & Definition \\
\hline Spiritual services & $\begin{array}{l}\text { Sites of spiritual, religious, or other forms of exceptional } \\
\text { personal meaning }\end{array}$ \\
Educational values & Sites that widen knowledge about plant and animal species \\
Inspiration & Sites that stimulate new thoughts, ideas or creative expressions \\
Aesthetic values & Sites of particular beauty \\
Social relations & Sites serving as meeting points with friends \\
Sense of place & Sites that foster a sense of authentic human attachment, in \\
& German langage commonly epitomized as Heimat ("home") \\
Cultural heritage values & Sites relevant to local history and culture \\
Recreation and ecotourism & $\begin{array}{l}\text { Sites used for recreational activities (walking, dog walking, } \\
\text { horse riding, swimming, gathering wild foods, angling, hunting, } \\
\text { etc.) }\end{array}$ \\
Unpleasantness & Sites that are neglected, abused, damaged, or unpleasant \\
Scariness & Sites that feel dangerous or threatening \\
Noisiness & Sites that are disturbingly noisy \\
\hline
\end{tabular}




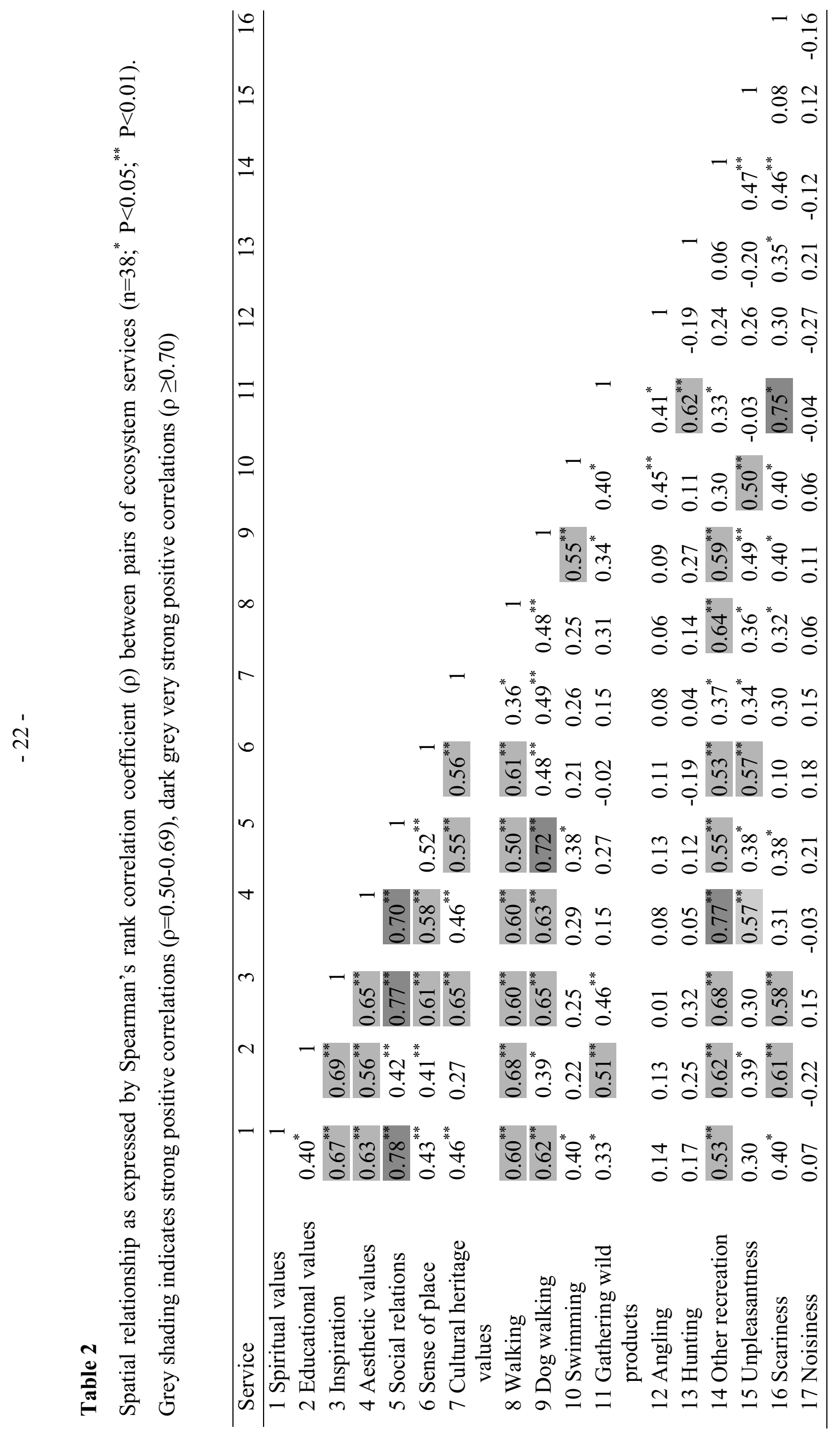




\section{Figure captions}

Fig. 1. Land cover of the Guttau study area.

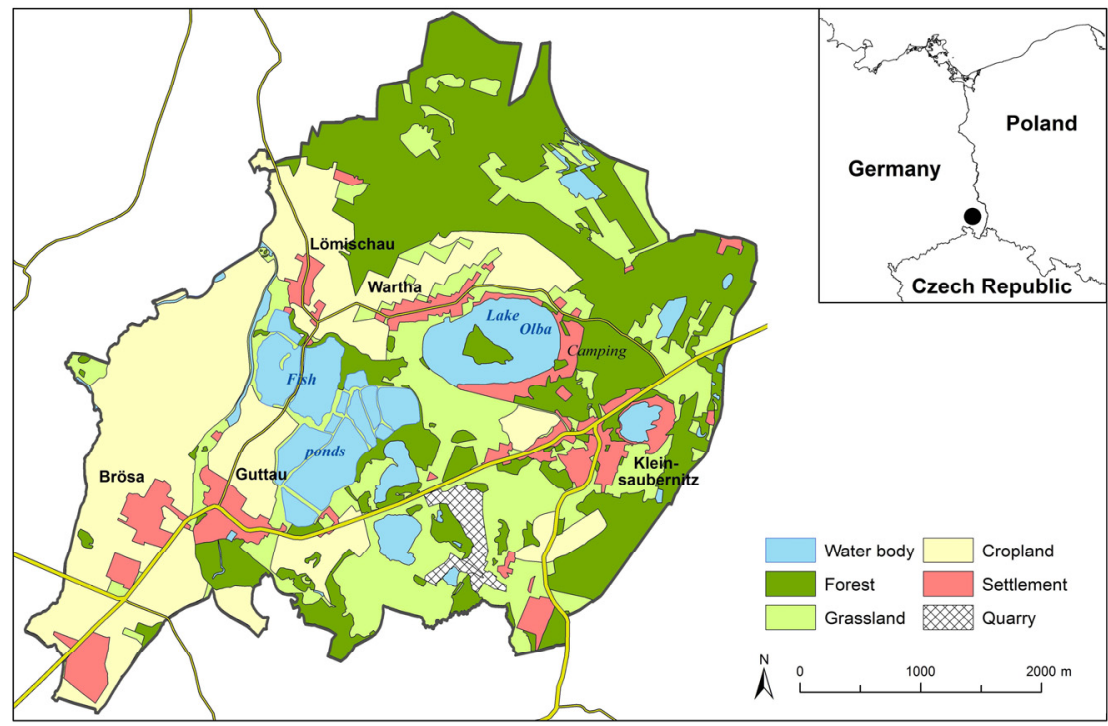

Fig. 2. Perceptions of cultural services (light grey, without recreation), recreational services (dark grey) and disservices (black) in the community. The x-axis indicates the number of entries of a specific (dis)service by the 93 respondents.

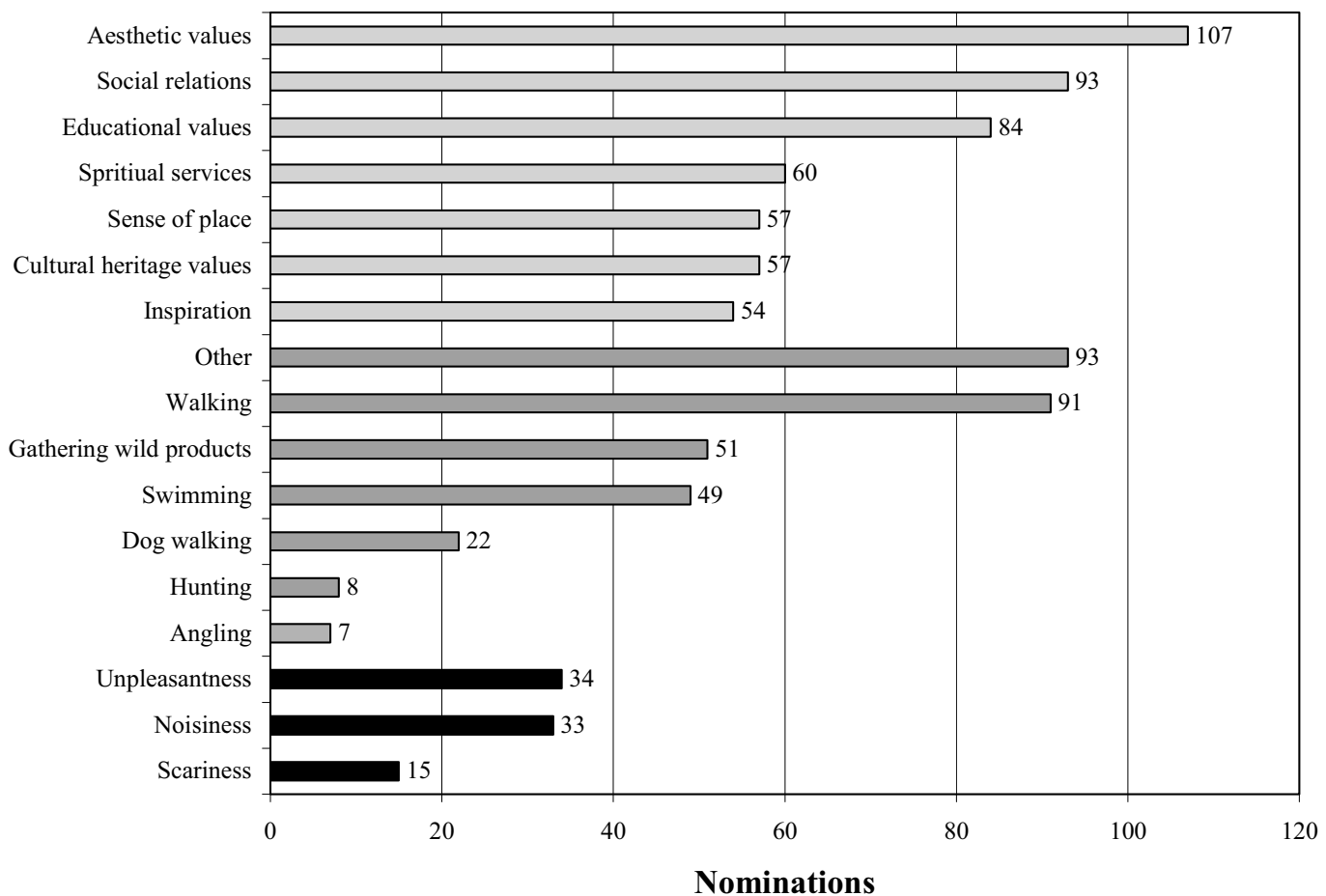


Fig. 3. Scatter plot of the two first axes of the multiple correspondence analysis (MCA). The active variables (black) represent the ecosystem services perceptions of every interviewee, and the supplementary variables (grey) are their social characteristics.

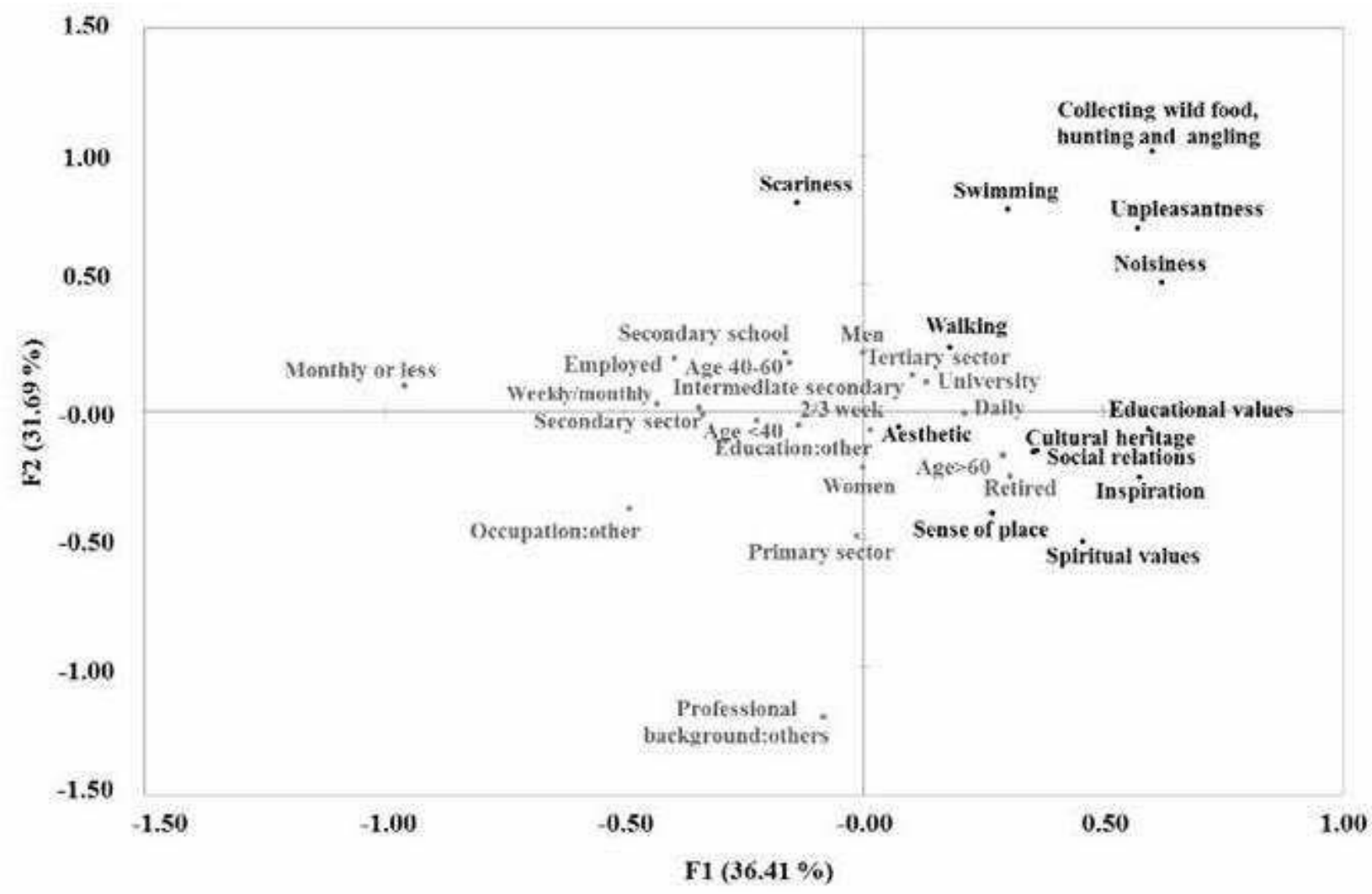


Fig. 4. Maps of individual cultural (dis)services.

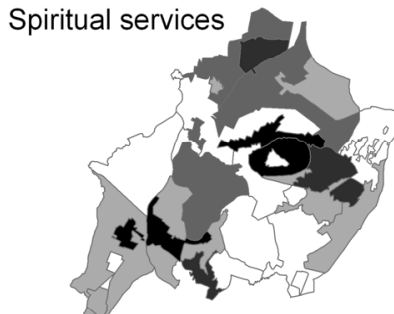

Aesthetic values

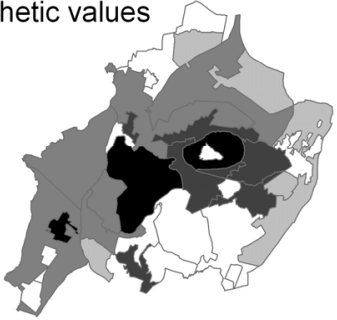

Cultural heritage values

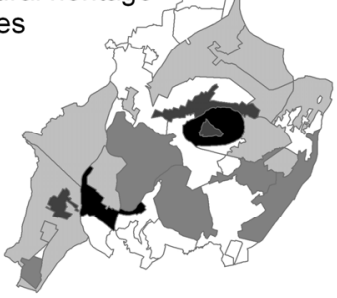

Swimming

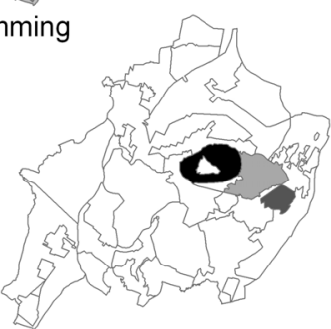

Hunting

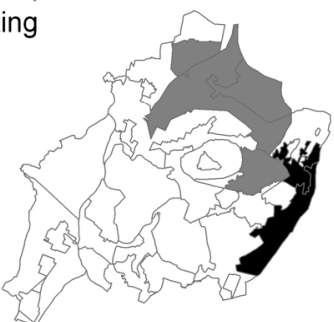

Scariness

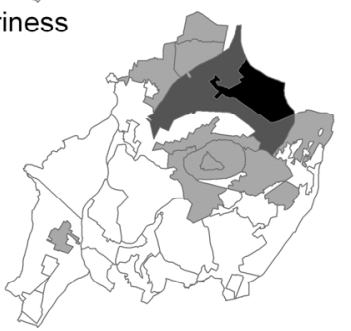

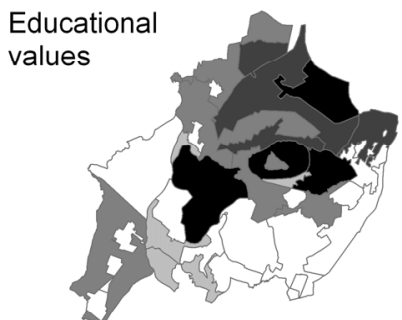

Social relations

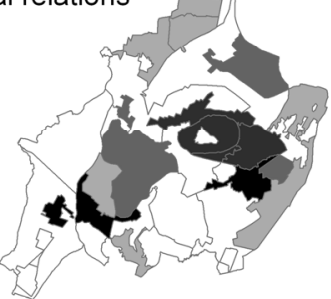

Walking
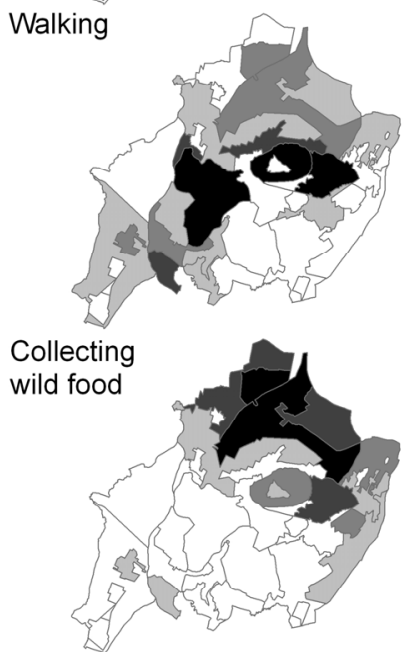

Other recreation

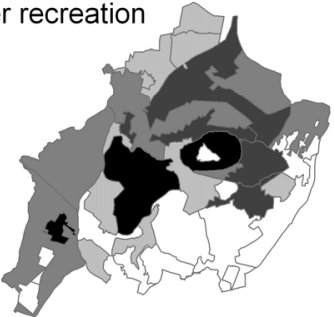

Noisiness

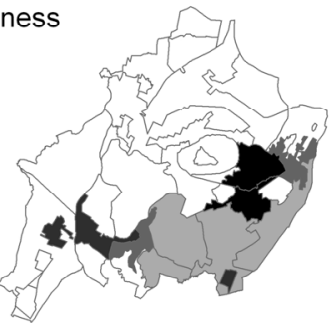

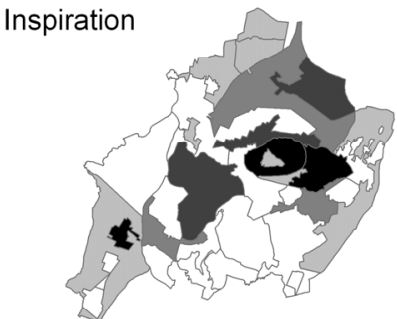

Sense of place

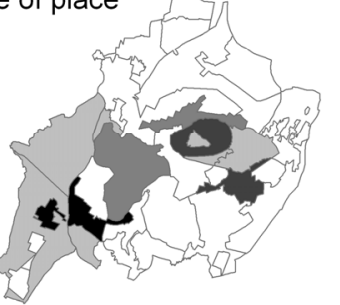

Dog walking

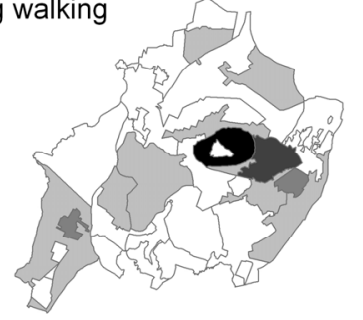

Angling

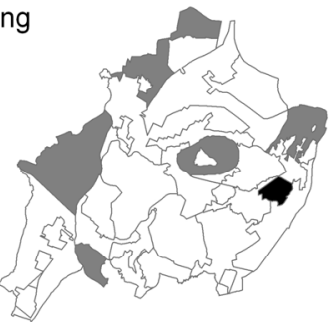

Unpleasantness

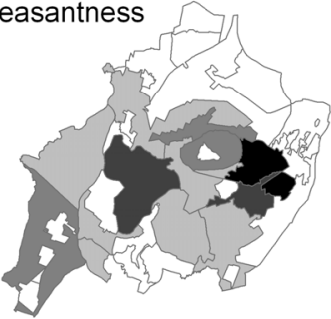

High

ES Values

(Quantiles) 
Fig. 5. Aggregated patterns of cultural ecosystem (dis)services: Intensity (A), richness (B) and diversity $(\mathrm{C})$ of cultural services, and intensity (D) of disservices.

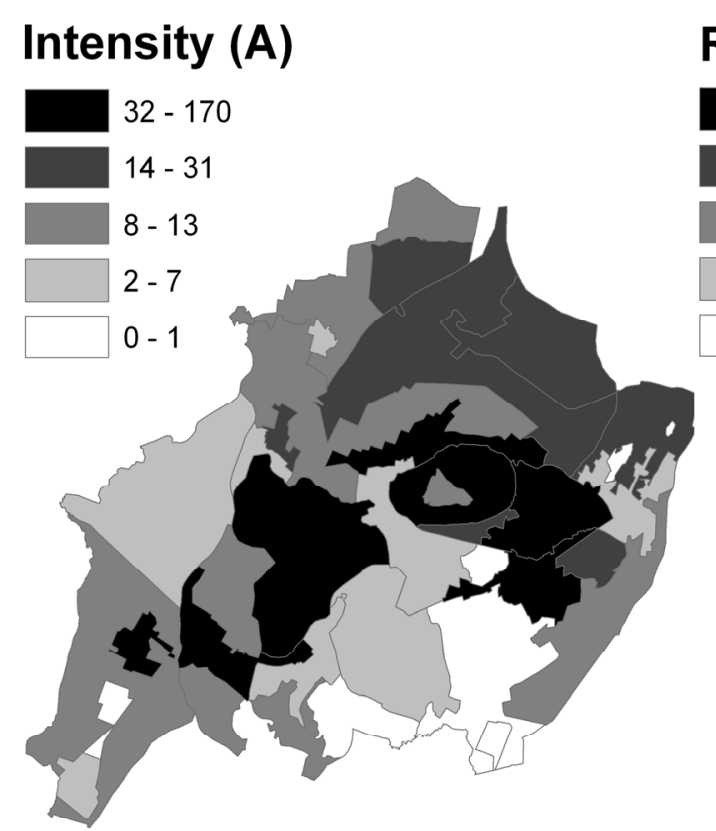

\section{Richness (B)}

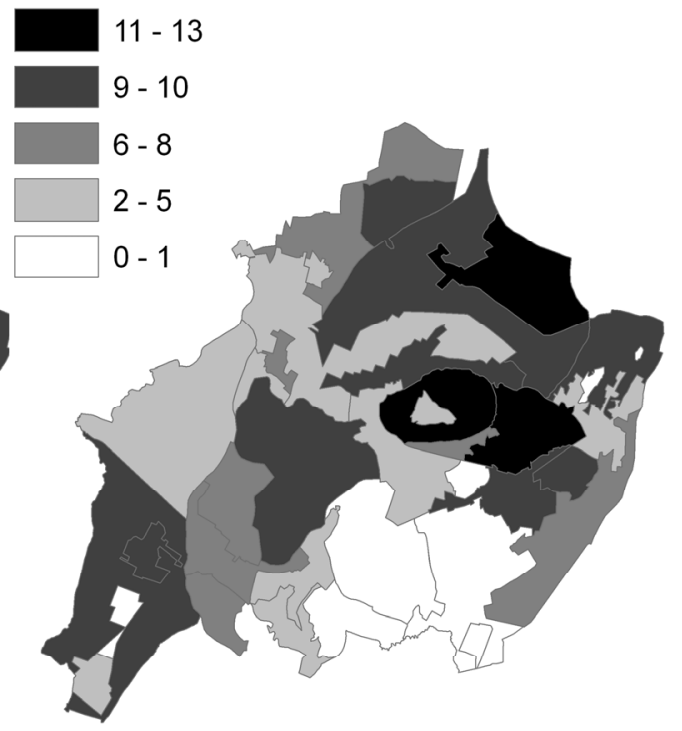

Diversity (C)

Intensity dis-services (D)
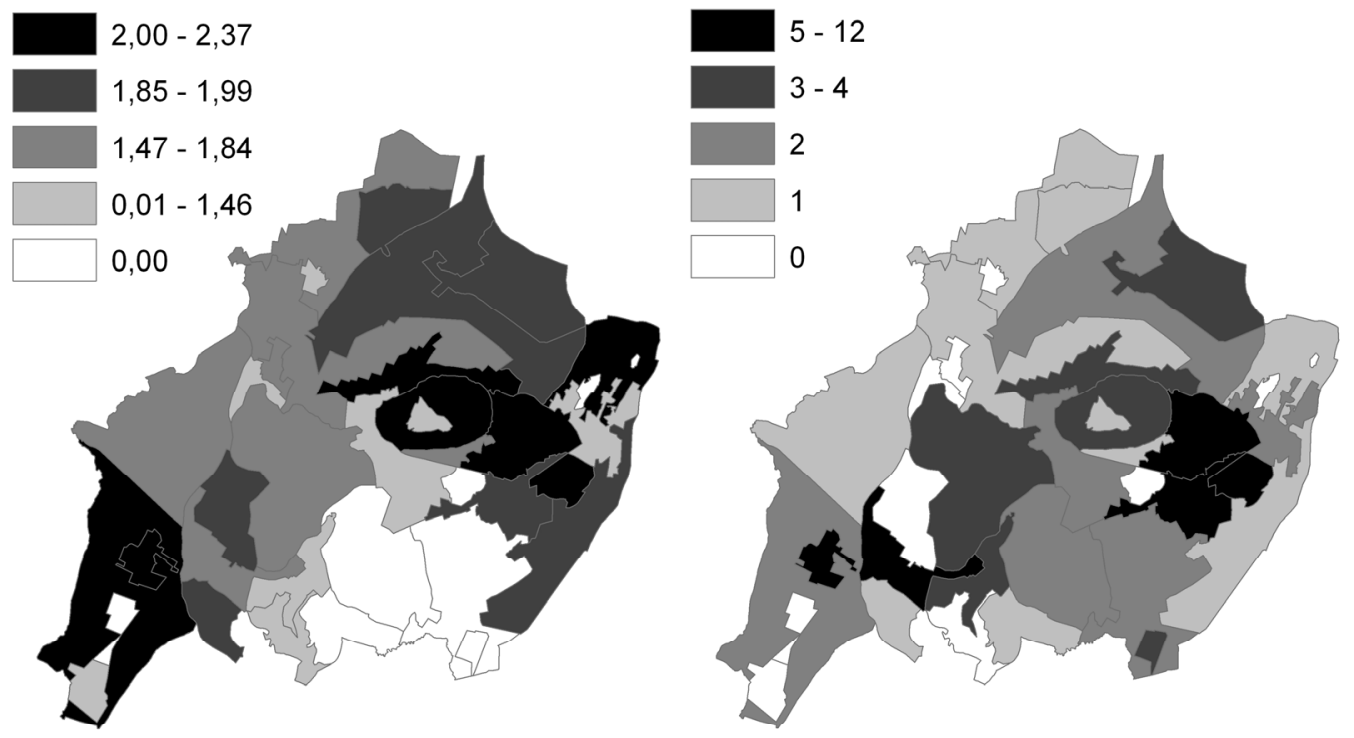
Fig. 6. Scatter plot of the two principal factors of the principal component analysis (PCA). Different colors and initials correspond to different types of land cover: $F=$ forest; $G$ $=$ grassland; $\mathrm{WB}=$ water body; $\mathrm{S}=$ settlement; $\mathrm{C}=$ cropland; $\mathrm{Q}=$ quarry. Numbers correspond to the number of land cover units.

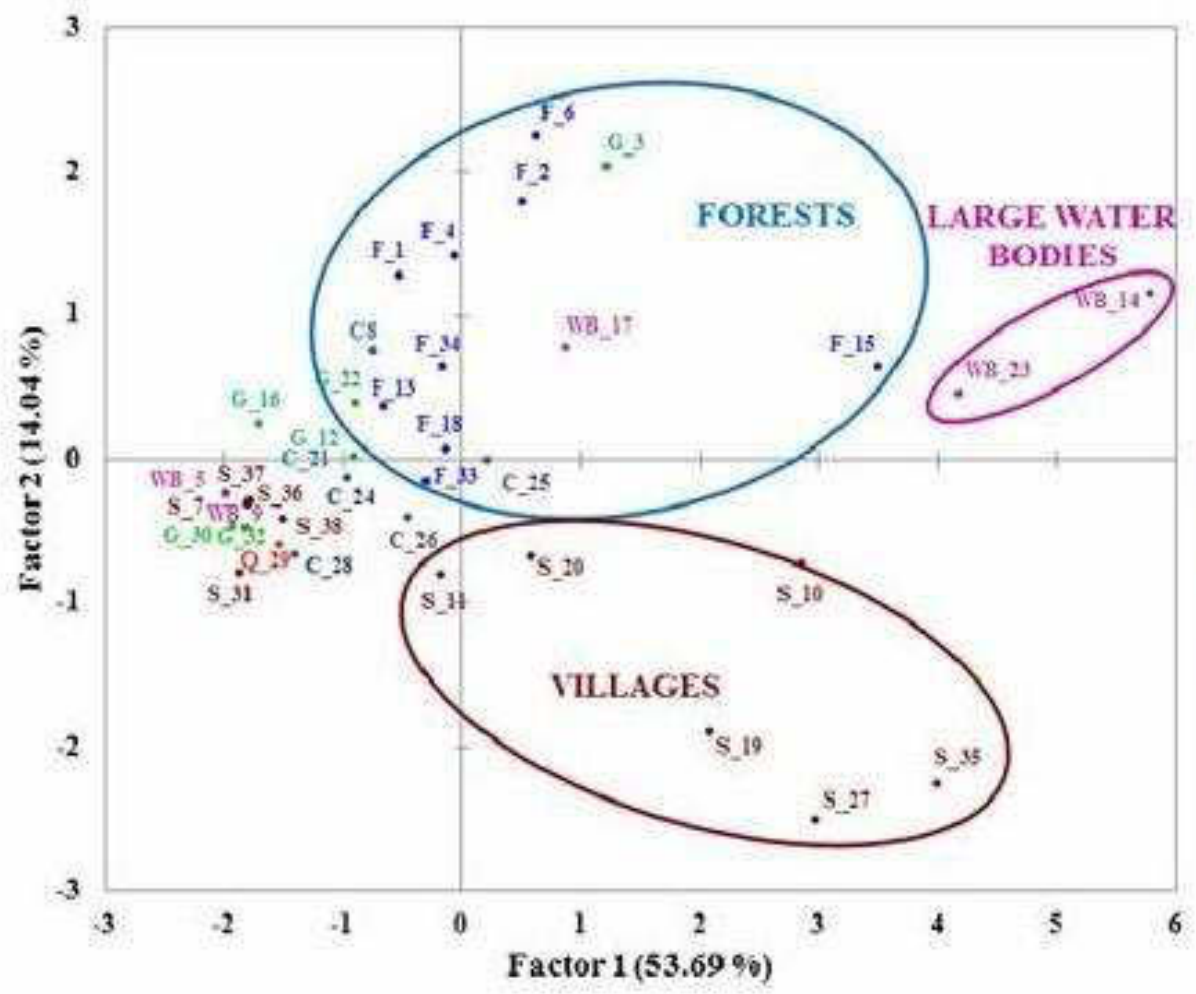

Forest (F)

Cropland (C)

Grassland (G)

Water body (WB)

Settlement (S)

Quarry (Q) 